\title{
Food diversity in West Africa: Case of the main traditional dishes consumed in Côte d'Ivoire
}

\author{
KUNINDJANI Adou Koffi * 1, GBAKAYORO Jean Brice 1, ANVOH Koutoua Yves Blanchard 1, BROU \\ Kouakou 1 \\ 1 Department of Food Sciences and Technology, Laboratory of Nutrition and Food Safety, Nangui Abrogoua \\ University, Abidjan, Côte d'Ivoire 02 BP 801 Abidjan 02, Côte d'Ivoire. \\ *Corresponding author: kunindjani@yahoo.fr Tel: +2250828 1593
}

Original submitted in on $16^{\text {th }}$ June 2020. Published online at www.m.elewa.org/journals/ on $31^{\text {st }}$ August 2020 https://doi.org/10.35759/JABs.152.9

\begin{abstract}
Objective: According to regional or ethnic affiliation, Ivoirians consume a variety of traditional dishes. This study aimed to discover the dietary diversity and determine the nutritional contribution of the Ivorian traditional dishes.

Methodology and results: For that, a family food survey was conducted in forty-four localities in different regions (North, South, East, Center and West). Households from these localities were interviewed using a questionnaire. The interview focused on the preparation of the most commonly consumed traditional dishes, selected based on the consumption frequency. Then, the physico-chemical characteristics of these dishes were determined. The results showed that Ivorian traditional dishes consist mainly of starchy basic dishes and side sauces. The main dishes consist of tubers and roots (yam, cassava, potato) or cereals (rice, corn, millet, sorghum.) and starchy fruits (plantain). The side sauces are cooked from vegetables (eggplants, seeds, tomatoes, okra, leaves, peppers, peanuts, and pistachios), proteins like fish, meat, poultry, molluscs, mushrooms, seafood and spices (salt, pepper).

The Ivorian traditional dishes provide a sufficient share of carbohydrates, proteins and lipids with average contents ranging respectively between 45 to $69 \%, 10$ to $20 \%$ and less than $35 \%$ of dry matter. In addition, these dishes provided sufficient energy ( 373.33 to $516.78 \mathrm{Kcal} / 100 \mathrm{~g} \mathrm{DM}$ ) and had low sodium, calcium and magnesium contents. Their iron contents were relatively good.

Conclusion and application of results: The Ivorian population's diets diversity is real and beneficial to them because the different dishes consumed provide the necessary nutrients for the proper functioning of the consumer's bodies. However, compliance with the principles of a good diet, particularly in terms of quantity, is essential to avoid pathologies by excess or by default.
\end{abstract}

Keywords: Dietary diversity, traditional dishes, chemical composition, Côte d'Ivoire

\section{INTRODUCTION}

Côte d'Ivoire is an African country with forest, savannah, arable land and suitable for agriculture. The two main export crops of the country are coffee and cocoa. It has also invested in the production of many nuts including those of cashew and cola. It is also the leading mango exporter to Europe and a major producer of plantains and dessert bananas (Minader, 2016). In terms of food crops (cassava, plantain, rice) intended mainly for domestic consumption, Côte d'Ivoire is also cited among the 
main African producers (Minader, 2016). What guarantees availability of these crops and allows different indigenous peoples to continue to make guided food choices, while remaining faithful to their eating habits acquired over many generations. This dietary diversity, influenced by cultural, regional and ethnic affiliation, makes it possible to establish a national food directory. In developing countries, dietary diversity is positively associated with nutritional adequacy (coverage of population nutritional needs). Studies have shown a correlation between dietary diversity indices, Food Variety Score, with the adequacy of macronutrient and micronutrient intake in the diet of non-breastfed children (Steyn et al., 2006; Kennedy et al., 2007), teenagers (Mirmiran, 2004) and adults (Foote et al., 2004 ; Arimond, 2010). One of the peculiarities of each country or each people is its culinary identity, which includes local dishes. There are very few information manuals on identifying traditional foods, vegetables and leafy vegetables from Africa and Asia according to FAO (1998). This is particularly true for Côte d'Ivoire. Many studies have focused on the regular consumption of starchy foods, cereals,

\section{MATERIAL AND METHODS}

Material: The survey was conducted using three cards, namely an information and consent card from the head of household, an information and consent card from the housewife and a household questionnaire. The plant material of the study consists of plantain banana (musa $A A B$ ), cassava (Manihot esculenta Crantz), rice (Oriza satva L.) and yam Bêtè-bêtè (Dioscorea alata) for the preparation of starchy dishes, namely plantain fufu (cooked and crushed plantain banana pulp to which red palm oil has been added), white attiéké (cooked semolina of cassava), attiéké red palm oil, the cooked white rice, plantain banana plus cassava foutou (plantain banana and cassava cooked and pounded), yam foutou (cooked and pounded yam), placali (cooked dough, based on fresh cassava and fermented cassava filtrate), conkondé (cooked dough, based on dried cassava flour), cassava foutou (cooked and pounded cassava). On the other hand, for the making of accompanying sauces; the namoukou sauce (based on the powder of dried leaves of the cheesemonger), baouin sauce (based on fresh leaves of cassava), light sauce (based on tomato and eggplant), eggplant sauce (eggplants based), biokosseu sauce (hot peppers and eggplant based), kpléba sauce legumes and ingredients by Africans in general and Ivorians in particular. However, a careful examination of the current state of available publications and documentation shows that in Côte d'Ivoire, work on dietary diversity is almost nonexistent. Dally et al. (2010) studied the nutritional efficiency of three Ivorian dishes, cabatoh (a food made with maize) with dah sauce in the north; the yam foutou with gouagouassou sauce in the center and the white rice cooked in seeds sauce in the West. However, considering the large number of ethnic groups (sixty) and ethnic groups (five) that Côte d'Ivoire abounds, several other standard dishes appearing in the eating habits of these peoples could be listed and the chemical composition of these dishes studied in order to determine the benefits brought to the body of consumers. The objective of this study was to identify the Ivorian traditional dishes of a larger section of the population. Specifically, a food consumption survey was carried out among the populations, followed by the determination of the chemical composition of these dishes.

(based on long kplé seeds powder), sran sauce (liana bark juice based), tchètchra sauce (based on potash, red palm oil and a small amount of eggplants), palm seeds and fresh okra sauce (mostly palm seeds and fresh okra) and fresh okra sauce (fresh okra based) ; the ingredients used were: eggplant (Solanum gilo), chili pepper (Capsicum fruescens), onion (Allium sativum), tomato (Solanum lycopersium), palm seeds (Elaesis gueneesis), cheesemonger leaves, cassava leaves, fresh okra (Hibiscus esculentus), long seeds of kplé (Irvingia gabonensis), red palm oil (Elaesis gueneesis), potash, liana bark, seeds of Akpi (Ricinodendron heudelotti) and spices. Protein sources such as dry or smoked herring fish, carp fish, meat (beef chops) and snails (Achatina achatina) were used to enrich the sauces. The ingredients used in the preparation of the studied dishes were purchased at the Locodjro market, in the municipality of Attécoubé, in Abidjan, Côte d'Ivoire.

\section{Methods}

Survey site: The survey was carried out on Ivorian territory in forty-four localities selected based on ethnic groups, climate and vegetation. These localities were: 
North: Korhogo, Dabakala, Madinani, Odienné, Séguéla, Sinématiali, Touba and Tiéningboué

South: Aboisso, Bianouan, Adzopé, Agboville, Dabou, Divo, Toupah, Grand-Lahou, Jacqueville, Fresco and Hiré

East: Agnibilékro, Appimandoum, Tanda and Koun-Fao

Center: Bouaflé, Béoumi, Dimbokro, Bongouanou, M'Bahiakro and Prikro

West: Bloléquin, Biankouma, Danané, Facobly, Daloa, Kouibly, Kounahiri, Man, Zuénoula, Sinfra, Zoukougbeu, Gagnoa, Soubré, Grand-Zattry and Oumé

Target population: This family food consumption survey, using a household questionnaire, was addressed to heads of household and the housewife, responsible for cooking in the household.

Inclusion criteria: Any Ivorian adult (man or woman) from the visited region, acting as head of household or responsible for the kitchen who gave their consent by signing the consent sheet participated in the study.

Non-inclusion criteria: Could not participate in this study, anyone who did not meet the inclusion criteria: men, heads of households, housewives non-adult and non-ivorians.

Exclusion criteria: Anyone eligible for the study who refused or stopped answering questions was excluded from the study.

Course of the investigation: The survey took place from April 21 to May 30, 2015. Before starting the household questionnaire, the consent of the head of the household and that of the housewife were requested using the consent cards. The interview took place in French or in local languages. The parameters asked of the respondents were based on socio-economic characteristics, the consumed traditional dishes. During the interview, no answer was suggested or guided. Nevertheless, the investigator could give explanations to

\section{RESULTS}

Characteristics of the study populations: Those interviewed were from all ethnic groups in Côte d'Ivoire, namely, Akan, Krou, Gour, North Mandé and South Mandé and distributed as follows (Figure 1).

- $36 \%$ of Akan (Abron, Abbey, Attié, Agni, Baoulé, Adjoukrou, Alladjan, Avikam) facilitate understanding of the question, in order to obtain reliable data.

Physico-chemical analysis of Ivorian traditional dishes: The starchy basic foods were dried in an oven at $45^{\circ} \mathrm{C}$ for $72 \mathrm{~h}$ while the sauces were freeze-dried. The dishes were reconstituted in the proportions $70 / 30$, i.e. $70 \mathrm{~g}$ of starch-based food and $30 \mathrm{~g}$ of the sauces. The moisture, dry matter contents and the ash content were determined according to the method AOAC (1995). The sodium, calcium, iron and magnesium contents were determined according to the method described by Pauwels et al. (1992) using a spectrophotometer. Protein content was determined using the Kjeldhal method (BIPEA, 1976). The determination of the lipid content was made according to the method using the soxhlet (BIPEA, 1976). The determination of total crude fiber was done according to the method AOAC (1990). The total carbohydrate content was calculated using the difference method, which takes into account the moisture, fat, protein and ash contents according to the following formula:

$\%$ Total carbohydrate $=100-(\%$ Fat $+\%$ Protein $+\%$ Ash $+\%$ Moisture)

The energy value was determined by calculation according to the specific coefficients for protein, total carbohydrate and fat (Atwater and Rosa, 1899) according to the following formula:

V. E. $($ Kcal $)=4 x$ Protein $+4 \times$ Total carbohydrate $+9 x$ Fat

Statistical analysis: The survey data were entered and analysed using SPSS 20 and Excel software. Data presented as mean \pm standard deviation were obtained by analysis of variance (ANOVA) using IBM SPSS STATISTICS version 19.0 software. The comparison of averages was done using the Duncan's Test at the $5 \%$ significance level.

- $14 \%$ of Gour (Sénoufo, Koulango, Djimini)

- $18 \%$ of Krou (Bété, Dida, Guéré, Wobé, Godié, Niamboua)

- $23 \%$ of North Mandé (Mahouka, Kouyaka, Odiénéka)

- $9 \%$ of South Mandé (Yacouba, Gouro, Gagou) 


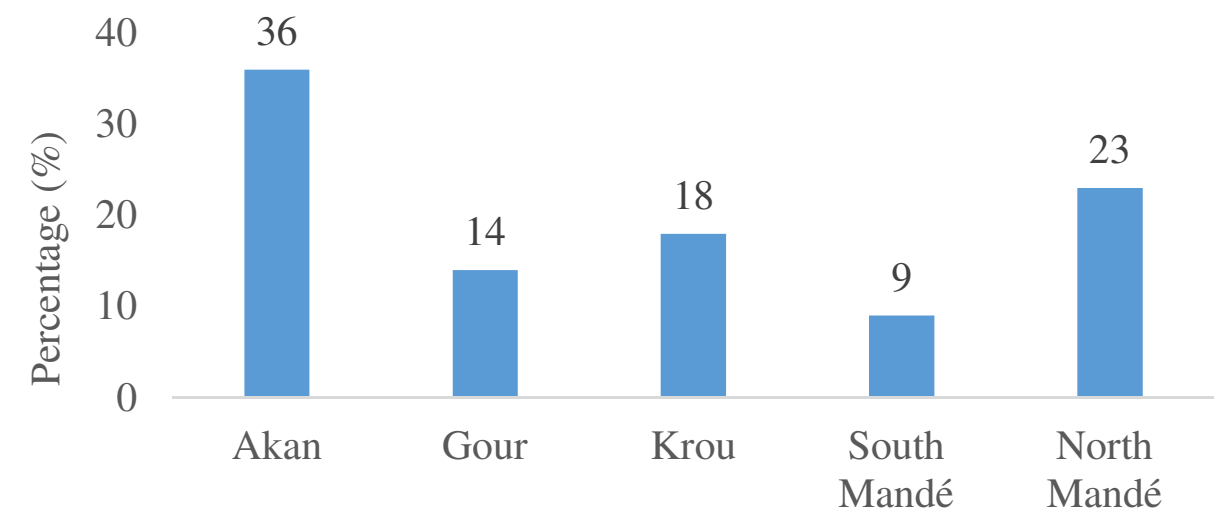

Figure 1: Ethnic groups of respondents

Food diversity in Côte d'Ivoire: The majority of staple foods are found practically throughout Ivorian territory (East, South, west, Center, North). However, food preferences are different depending on the geographic or ethnic origins of the populations.

Main dishes of Ivorian populations: Table 1 presents the main starchy staple foods of the Ivorian populations according to their geographical origin. These dishes are made from tubers and roots (yam, cassava, potato and cocoyam), cereals (rice, maize, millet, sorghum) and fruit (plantain banana).
Main Ivorian sauces accompanying starchy dishes: The main local Ivorian sauces are listed in Table 2. They have been classified according to geographic areas. They are mainly made up of vegetables, leafy vegetables and spices.

Main sources of protein consumed by Ivorian: The main sources of protein consumed by Ivorian are shown in Table 3. These are mainly fish, meats, game, crabs, eggs, molluscs, poultry, snails, shrimp and mushrooms.

Table 1: Main starchy dishes of Ivorian populations

\begin{tabular}{|c|c|c|c|c|c|}
\hline & East & South & West & Center & North \\
\hline $\begin{array}{l}\text { Main starchy } \\
\text { ivorian } \\
\text { traditional } \\
\text { dishes }\end{array}$ & $\begin{array}{l}\text { Yam foutou }{ }^{1} \\
\text { Cocoyam foutou }^{1} \\
\text { Plantain foutou }^{1} \\
\text { Boiled yam } \\
\text { Boiled cocoyam } \\
\text { Boiled plantain } \\
\text { Rice } \\
\text { Conkondé }^{1} \\
\text { Cabato }^{1} \\
\text { Bankou }^{1} \\
\text { Mash yam }^{\text {Boiled potatoes }} \\
\text { Mash cocoyam } \\
\text { Braised yam }\end{array}$ & $\begin{array}{l}\text { Plantain foutou }{ }^{1} \\
\text { White attiéké }^{2} \\
\text { Attiéké red palm } \\
\text { oil }^{2} \\
\text { Plantain fufu }{ }^{2} \\
\text { Rice } \\
\text { Placali }{ }^{1} \\
\text { Boiled plantain } \\
\text { boiled potatoes } \\
\text { Yam foutou }^{1} \\
\text { Cocoyam foutou } \\
1 \\
\text { Boiled yam } \\
\text { Braised } \\
\text { cocoyam } \\
\text { Braised plantain }\end{array}$ & $\begin{array}{l}\text { Rice } \\
\text { Cassava foutou }^{1} \\
\text { Plantain foutou }^{1} \\
{ }^{1} \text { Boiled cassava } \\
\text { Braised cassava } \\
\text { Placali }^{1} \\
\text { Yam foutou }^{1} \\
\text { Boiled cocoyam } \\
\text { Boiled yam } \\
\text { Boiled plantain } \\
\text { Boiled potatoes } \\
\text { Conkondé }{ }^{1} \\
\text { White attiéké }^{2} \\
\text { Cabato }{ }^{1}\end{array}$ & $\begin{array}{l}\text { Yam foutou }{ }^{1} \\
\text { Plantain foutou }{ }^{1} \\
\text { Placali }{ }^{1} \\
\text { Rice } \\
\text { Cocoyam foutou } \\
1 \\
\text { White attiéké }{ }^{2} \\
\text { Boiled yam } \\
\text { Boiled plantain } \\
\text { Boiled cocoyam } \\
\text { Braised yam } \\
\text { Braised cocoyam } \\
\text { Braised plantain } \\
\text { Cabato }{ }^{1} \\
\text { Conkondé }{ }^{1}\end{array}$ & $\begin{array}{l}\text { Cabato }{ }^{1} \\
\text { Yam foutou }^{1} \\
\text { Cocoyam foutou } \\
1 \\
\text { Boiled yam } \\
\text { Conkondé }{ }^{1} \\
\text { Rice } \\
\text { Boiled potatoes } \\
\text { Boiled cassava } \\
\text { Braised yam } \\
\text { Braised } \\
\text { cocoyam } \\
\text { White attiéké }^{2} \\
\text { Cassava foutou }^{1} \\
\text { Placali }^{1}\end{array}$ \\
\hline $\begin{array}{l}\text { Form of } \\
\text { consumption }\end{array}$ & $\begin{array}{l}\text { Paste }^{1} \\
\text { Boiled } \\
\text { Mash } \\
\text { Braised }\end{array}$ & $\begin{array}{l}\text { Semolina }{ }^{2} \\
\text { Paste }{ }^{1} \\
\text { Boiled }\end{array}$ & $\begin{array}{l}\text { Semolina }{ }^{2} \\
\text { Paste }^{1} \\
\text { Boiled } \\
\text { Braised }\end{array}$ & $\begin{array}{l}\text { Semolina }{ }^{2} \\
\text { Paste }{ }^{1} \\
\text { Boiled } \\
\text { Braised }\end{array}$ & $\begin{array}{l}\text { Semolina }{ }^{2} \\
\text { Paste }^{1} \\
\text { Boiled } \\
\text { Braised }\end{array}$ \\
\hline
\end{tabular}


Table 2: Main Ivorian sauces accompanying starchy dishes

\begin{tabular}{|c|c|c|c|c|c|}
\hline & East & South & West & Center & North \\
\hline Local sauces & $\begin{array}{l}\text { Eggplants } \\
\text { sauce }^{3} \\
\text { Fresh okra }^{\text {sauce }^{2}} \\
\text { Dry okra sauce }^{2} \\
\text { Palm seeds } \\
\text { sauce }^{2} \\
\text { Light sauce }^{1} \\
\text { Gnangnan }^{2} \\
\text { sauce }^{2} \\
\text { Pistachio } \\
\text { sauce } \\
\\
\text { Peanuts sauce } \\
2 \\
\text { Leaf sauce }^{2}\end{array}$ & $\begin{array}{l}\text { Palm seeds } \\
\text { sauce }^{2} \\
\text { Eggplants } \\
\text { sauce }^{3} \\
\text { Biokosseu }^{2} \\
\text { sauce }^{2} \\
\text { Dry okra sauce } \\
2 \\
\text { Fresh okra } \\
\text { sauce }^{2} \\
\text { Light sauce }^{1} \\
\text { Tchêtchra } \\
\text { sauce }^{2} \\
\text { Leaf sauce }^{2} \\
\text { Peanut sauce } \\
\text { 2 } \\
\text { Pistachio sauce } \\
2\end{array}$ & $\begin{array}{l}\text { Palm seeds } \\
\text { sauce }^{2} \\
\text { Light sauce }^{1} \\
\text { Baouin sauce } \\
\text { Kpléba sauce }^{2} \\
\text { Eggplants }^{2} \\
\text { sauce }^{3} \\
\text { Fresh okra } \\
\text { sauce }^{2} \\
\text { Dry okra sauce }^{2} \\
\text { Sran sauce }{ }^{2} \\
\text { Leaf sauce }^{2} \\
\text { Peanuts sauce } \\
2 \\
\text { Pistachio } \\
\text { sauce }^{2}\end{array}$ & $\begin{array}{l}\text { Gouagouassou } \\
\text { sauce }^{2} \\
\text { Eggplants sauce }^{3} \\
\text { Dry okra sauce }^{2} \\
\text { Fresh okra sauce }^{2} \\
\text { Namoukou sauce }^{2} \\
\text { Palm seeds sauce } \\
2 \\
\text { Leaf sauce }^{2} \\
\text { Pistachio sauce }{ }^{2} \\
\text { Light sauce }^{1} \\
\text { Peanut sauce } \\
{ }^{2} \\
\text { Gnangnan sauce }^{2}\end{array}$ & $\begin{array}{l}\text { Peanuts sauce }{ }^{2} \\
\text { Leaf sauce }^{2} \\
\text { Eggplants sauce }^{3} \\
\text { Light sauce }^{1} \\
\text { Pistachio sauce }^{2} \\
\text { Fresh okra sauce } \\
2 \\
\text { Dry okra sauce }{ }^{2} \\
\text { Palm seeds sauce } \\
2 \\
\text { Soumara sauce }^{2}\end{array}$ \\
\hline $\begin{array}{l}\text { Form of } \\
\text { consumption }\end{array}$ & & Liquid & Semi-liquid & Thick & \\
\hline
\end{tabular}

1 means that the sauces are consumed only liquid;

2 means that the sauces are consumed semi-liquid or thick;

3 these sauces are consumed liquid, semi-liquid or thick.

${ }^{4}$ sauces are consumed only thick.

Table 3: Main sources of protein consumed by Ivorian

\begin{tabular}{|c|c|c|c|c|c|}
\hline & East & South & West & Center & North \\
\hline $\begin{array}{l}\text { Protein } \\
\text { main } \\
\text { sources }\end{array}$ & $\begin{array}{l}\text { Meats } \\
\text { Fish } \\
\text { Mushrooms } \\
\text { Molluscs } \\
\text { Crustaceans } \\
\text { poultry } \\
\text { Eggs }\end{array}$ & $\begin{array}{l}\text { Fish } \\
\text { Meats } \\
\text { Snails } \\
\text { Crabs } \\
\text { Shrimp } \\
\text { Poultry } \\
\text { Eggs } \\
\text { Mushrooms }\end{array}$ & $\begin{array}{l}\text { Frogs } \\
\text { Meats } \\
\text { Fish } \\
\text { Mushrooms } \\
\text { Snails } \\
\text { Eggs } \\
\text { Crabs } \\
\text { Shrimp }\end{array}$ & $\begin{array}{l}\text { Meats } \\
\text { Fish } \\
\text { Game } \\
\text { Snails } \\
\text { Eggs } \\
\text { Mushrooms } \\
\text { Crabs } \\
\text { Shrimp } \\
\text { Poultry }\end{array}$ & $\begin{array}{l}\text { Fish } \\
\text { Meats } \\
\text { Poultry } \\
\text { Mushrooms } \\
\text { Eggs } \\
\text { Crabs }\end{array}$ \\
\hline $\begin{array}{l}\text { Cooking } \\
\text { modes }\end{array}$ & $\begin{array}{l}\text { Cooked in water, } \\
\text { Oven-baked, } \\
\text { Braised, } \\
\text { Cooked in a leaf, } \\
\text { Fried/grilled }\end{array}$ & $\begin{array}{l}\text { Cooked in water, } \\
\text { Grilled / fried } \\
\text { Oven-back, } \\
\text { Braised, } \\
\text { Cooked in a leaf }\end{array}$ & $\begin{array}{l}\text { Cooked in water, } \\
\text { Grilled / fried } \\
\text { Oven-back, } \\
\text { Braised, } \\
\text { Cooked in a leaf }\end{array}$ & $\begin{array}{l}\text { Cooked in water, } \\
\text { Grilled / fried } \\
\text { Oven-back, } \\
\text { Braised, } \\
\text { Cooked in a leaf }\end{array}$ & $\begin{array}{l}\text { Cooked in water, } \\
\text { Grilled / fried, } \\
\text { Cooked in a leaf } \\
\text { Oven-back, } \\
\text { Braised }\end{array}$ \\
\hline
\end{tabular}

Biochemical composition of Ivorian traditional dishes: The table 4 presents the biochemical composition and the energy value of Ivorian traditional dishes. The Ivorian main traditional dishes consumed are the foutou of ripe plantain banana and cassava with eggplant sauce (RPCF/EGS), the green plantain banana and cassava with biokosseu sauce (GPCF/BIS), white attiéké with light sauce (WAT/LS), attiéké red palm oil with light sauce (ATR/LS), cassava foutou with sran sauce (CF/SRS), cassava foutou with kpléba sauce (CF/KPS), cooked white rice with baouin sauce (WRI/BAS), ripe plantain banana and cassava foutou with tchètchra sauce (RPCF/TCS), yam foutou with namoukou sauce (YF/NAS), plantain banana fufu with light sauce (PFF/LS), conkondé with fresh okra sauce (CON/FOS) and placali with palm seed and fresh okra 
sauce (PLA/POS). Most of these foods (WAT/LS, CON/FOS, GPCF/BIS, RPCF/EGS, RPCF/TCS, YF/NAS and CF/SRS) had high levels of carbohydrate with values between 56.61 and $69.01 \mathrm{~g} / 100 \mathrm{~g}$ of dry matter. The CF/KPS and the PLA/POS had normal carbohydrate amounts of $55 \mathrm{~g} / 100 \mathrm{~g}$ of dry matter while the PFF/LS, I'ATR/LS and the WRI/BAS had carbohydrate values between 45.65 and $48.91 \mathrm{~g} / 100 \mathrm{~g}$ of dry matter. All dishes had low lipid contents with values between 4.43 and $29.78 \mathrm{~g} / 100 \mathrm{~g} \mathrm{DM}$, with the exception of PFF/LS, which had a normal amount 31.10 $\mathrm{g} / 100 \mathrm{~g}$ of dry matter.
Most dishes (WAT/LS, ATR/LS, RPCF/EGS, PFF/LS, YF/NAS and WRI/BAS) had normal protein contents with values between 12.62 and $14.34 \mathrm{~g} / 100 \mathrm{~g} \mathrm{DM}$. On the other hand, the CON/FOS and the CF/SRS contained very few respectively 10.44 and $10.94 \mathrm{~g} / 100 \mathrm{~g} \mathrm{DM}$, while the GPCF/BIS, the RPCF/TCS, the CF/SRS and the PLAIPOS had higher values between 16.59 and $20.41 \mathrm{~g} / 100 \mathrm{~g}$ DM. All these dishes also brought enough energy ( 373.33 and $516.78 \mathrm{Kcal} / 100 \mathrm{~g} \mathrm{DM}$ ). The fiber contents were low and were between 2.1 and $6.76 \mathrm{~g} /$ $100 \mathrm{~g}$ of dry matter.

Table 4: Chemical composition of Ivorian traditional dishes

\begin{tabular}{l|l|l|l|l|l}
\hline Dishes & $\begin{array}{l}\text { Proteins } \\
\text { (g/100 g DM) }\end{array}$ & $\begin{array}{l}\text { Fats } \\
\text { (g/100 g DM) }\end{array}$ & $\begin{array}{l}\text { fibres } \\
\text { (g/100 g DM) }\end{array}$ & $\begin{array}{l}\text { Carbohydrates } \\
\text { (g/100 g DM) }\end{array}$ & $\begin{array}{l}\text { E. V. (Kcal/100 g } \\
\text { DM) }\end{array}$ \\
\hline WAT/LS & $12.67 \pm 0.02^{\mathrm{h}}$ & $9.52 \pm 0.01^{\mathrm{i}}$ & $3.1 \pm 0.2^{\mathrm{e}}$ & $68.73 \pm 0.02^{\mathrm{c}}$ & $411.32 \pm 0.05^{\mathrm{h}}$ \\
ATR/LS & $12.62 \pm 0.02^{\mathrm{i}}$ & $28.06 \pm 0.02^{\mathrm{c}}$ & $5.1 \pm 0.1^{\mathrm{b}}$ & $48.91 \pm 0.59^{\mathrm{j}}$ & $498.73 \pm 2.79^{\mathrm{c}}$ \\
CON/FOS & $10.44 \pm 0.04^{\mathrm{j}}$ & $18.72 \pm 0.01^{\mathrm{d}}$ & $3.04 \pm 0.05^{\mathrm{f}}$ & $60.75 \pm 0.02^{\mathrm{e}}$ & $453.32 \pm 0.05^{\mathrm{d}}$ \\
GPCF/BIS & $20.11 \pm 0.01^{\mathrm{b}}$ & $10.10 \pm 0.02^{\mathrm{h}}$ & $3.86 \pm 0.1^{\mathrm{cg}}$ & $59.37 \pm 0.01^{\mathrm{f}}$ & $408.84 \pm 0.09^{\mathrm{i}}$ \\
RPCF/EGS & $14.31 \pm 0.03^{\mathrm{e}}$ & $8.73 \pm 0.02^{\mathrm{k}}$ & $4.1 \pm 0.1^{\mathrm{c}}$ & $67.01 \pm 0.02^{\mathrm{d}}$ & $403.91 \pm 0.10^{\mathrm{j}}$ \\
RPCF/TCS & $16.59 \pm 0.01^{\mathrm{d}}$ & $16.06 \pm 0.05^{\mathrm{e}}$ & $3.9 \pm 0.05^{\mathrm{cg}}$ & $56.61 \pm 0.17^{\mathrm{g}}$ & $437.39 \pm 0.08^{\mathrm{e}}$ \\
PFF/LS & $13.55 \pm 0.01^{\mathrm{g}}$ & $31.10 \pm 0.01^{\mathrm{a}}$ & $3.45 \pm 0.06^{\mathrm{dg}}$ & $45.65 \pm 0.01^{\mathrm{l}}$ & $516.78 \pm 0.08^{\mathrm{a}}$ \\
YF/NAS & $14.34 \pm 0.02^{\mathrm{e}}$ & $4.43 \pm 0.03^{\mathrm{l}}$ & $3.0 \pm 0.2^{\mathrm{g}}$ & $69.01 \pm 0.05^{\mathrm{a}}$ & $373.33 \pm 0.15^{\mathrm{f}}$ \\
CF/KPS & $20.41 \pm 0.02^{\mathrm{a}}$ & $13.79 \pm 0.00^{\mathrm{g}}$ & $3.5 \pm 0.05^{\mathrm{d}}$ & $55.98 \pm 0.01^{\mathrm{h}}$ & $429.71 \pm 0.04^{\mathrm{f}}$ \\
CF/SRS & $10.94 \pm 0.02^{\mathrm{k}}$ & $9.27 \pm 0.01^{\mathrm{j}}$ & $6.76 \pm 0.1^{\mathrm{a}}$ & $68.90 \pm 0.18^{\mathrm{b}}$ & $402.87 \pm 0.58^{\mathrm{k}}$ \\
PLA/POS & $17.11 \pm 0.02^{\mathrm{c}}$ & $14.26 \pm 0.00^{\mathrm{f}}$ & $4.1 \pm 0.05^{\mathrm{c}}$ & $55.62 \pm 0.02^{\mathrm{i}}$ & $419.34 \pm 0.03^{\mathrm{g}}$ \\
WRI/BAS & $14.19 \pm 0.01^{\mathrm{f}}$ & $29.78 \pm 0.01^{\mathrm{b}}$ & $2.1 \pm 0.1^{\mathrm{h}}$ & $47.64 \pm 0.03^{\mathrm{k}}$ & $515.41 \pm 0.06^{\mathrm{b}}$ \\
\hline
\end{tabular}

E. V.: energy value, DM: dry matter. The values are averages of three determinations $(n=3)$. In each column, the assigned values of the same letters are not significantly different at the $5 \%$ threshold. RPCF/EGS : foutou of ripe plantain banana and cassava with eggplant sauce, GPCF/BIS : green plantain and cassava foutou with biokosseu sauce, WAT/LS : white attiéké with light sauce, ATR/LS attiéké red palm oil with light sauce, CF/SRS : cassava foutou with sran sauce, CF/KPS : cassava foutou with kpléba sauce, WRI/BAS : cooked white rice with baouin sauce, RPCF/TCS : ripe plantain and cassava foutou with tchètchra sauce, YF/NAS : yam foutou with namoukou sauce, PFF/LS : plantain fufu with light sauce, CON/FOS : conkondé with fresh okra sauce and PLA/POS : placali with palm seed and fresh okra sauce.

Mineral composition of Ivorian dishes: The composition of mineral elements such as sodium, iron, calcium and magnesium in typical Ivorian dishes is recorded in table 5 . All these dishes have low levels of sodium, calcium, and magnesium with values respectively ranging from 126.02 and $140.52 \mathrm{mg} / 100 \mathrm{~g}$ of DM for sodium, 29.52 and $258.78 \mathrm{mg} / 100 \mathrm{~g}$ of DM for calcium, 32.62 and $39.06 \mathrm{mg} / 100 \mathrm{~g}$ of DM for magnesium. Nevertheless, most of these dishes (WAT/LS, ATR/LS, CON/FOS, RPCF/EGS, PFF/LS, YF/NAS, CF/KPS, PLA/POS and WRI/BAS) had a high iron content with values between 7.65 and $8.68 \mathrm{mg} / 100$ g DM, while some (GPCF/BIS, RPCF/TCS, CF/SRS) contained small amounts of iron, between 5.63 and 6.01 $\mathrm{mg} / 100 \mathrm{~g} \mathrm{DM}$. 
Table 5: Mineral content of Ivorian dishes (mg / $100 \mathrm{~g} \mathrm{DM}$ )

\begin{tabular}{l|l|l|l|l}
\hline Dishes & Sodium & Iron & Calcium & Magnesium \\
\hline WAT/LS & $131.05 \pm 0.05^{\mathrm{f}}$ & $8.32 \pm 0.02^{\mathrm{c}}$ & $42.01 \pm 0.01^{\mathrm{g}}$ & $34.94 \pm 0.01^{\mathrm{i}}$ \\
ATR/LS & $132.14 \pm 0.2^{\mathrm{d}}$ & $8.25 \pm 0.01^{\mathrm{d}}$ & $43.09 \pm 0.00^{\mathrm{e}}$ & $33.9 \pm 0.02^{\mathrm{j}}$ \\
CON/FOS & $125.22 \pm 0.02^{\mathrm{k}}$ & $8.68 \pm 0.01^{\mathrm{a}}$ & $33.37 \pm 0.01^{\mathrm{h}}$ & $37.82 \pm 0.02^{\mathrm{c}}$ \\
GPCF/BIS & $140.52 \pm 0.02^{\mathrm{a}}$ & $6.01 \pm 0.01^{\mathrm{i}}$ & $30.01 \pm 0.01^{\mathrm{j}}$ & $37.08 \pm 0.01^{\mathrm{e}}$ \\
RPCF/EGS & $134.25 \pm 0.00^{\mathrm{c}}$ & $8.48 \pm 0.02^{\mathrm{b}}$ & $193.55 \pm 0.01^{\mathrm{d}}$ & $36.06 \pm 0.01^{\mathrm{h}}$ \\
RPCF/TCS & $136.70 \pm 0.00^{\mathrm{b}}$ & $5.96 \pm 0.01^{\mathrm{j}}$ & $31.60 \pm 0.02^{\mathrm{i}}$ & $36.61 \pm 0.02^{\mathrm{g}}$ \\
PFF/LS & $131.60 \pm 0.01^{\mathrm{e}}$ & $8.32 \pm 0.02^{\mathrm{c}}$ & $42.20 \pm 0.04^{\mathrm{f}}$ & $32.62 \pm 0.02^{\mathrm{l}}$ \\
YF/NAS & $129.51 \pm 0.02^{\mathrm{g}}$ & $7.85 \pm 0.01^{\mathrm{f}}$ & $258.78 \pm 0.02^{\mathrm{a}}$ & $37.61 \pm 0.01^{\mathrm{d}}$ \\
CF/KPS & $127.11 \pm 0.01^{\mathrm{i}}$ & $7.65 \pm 0.00^{\mathrm{h}}$ & $29.52 \pm 0.01^{\mathrm{l}}$ & $39.06 \pm 0.01^{\mathrm{a}}$ \\
CF/SRS & $131.59 \pm 0.01^{\mathrm{e}}$ & $5.63 \pm 0.02^{\mathrm{k}}$ & $29.70 \pm 0.02^{\mathrm{k}}$ & $33.11 \pm 0.01^{\mathrm{k}}$ \\
PLA/POS & $127.79 \pm 0.02^{\mathrm{h}}$ & $7.80 \pm 0,00 \mathrm{~g}$ & $256.19 \pm 0.02^{\mathrm{b}}$ & $38.64 \pm 0.00^{\mathrm{b}}$ \\
WRI/BAS & $126.02 \pm 0.01^{\mathrm{j}}$ & $8.04 \pm 0,01^{\mathrm{e}}$ & $230.63 \pm 0.03^{\mathrm{c}}$ & $36,79 \pm 0.01^{\mathrm{f}}$
\end{tabular}

DM: dry matter. The values are averages of three determinations $(n=3)$. In each column, the assigned values of the same letters are not significantly different at the $5 \%$ threshold.

RPCF/EGS : foutou of ripe plantain banana and cassava with eggplant sauce, GPCF/BIS : green plantain banana and cassava foutou with biokosseu sauce, WAT/LS : white attiéké with light sauce, ATR/LS attiéké red palm oil with light sauce, CF/SRS: cassava foutou with sran sauce, CF/KPS : cassava foutou with kpléba sauce, WRI/BAS : cooked white rice with baouin sauce, RPCF/TCS : ripe plantain and cassava foutou with tchètchra sauce, YF/NAS : yam foutou with namoukou sauce, PFF/LS : plantain banana fufu with light sauce, CON/FOS : conkondé with fresh okra sauce and PLA/POS : placali with palm seed and fresh okra sauce.

\section{DISCUSSION}

The objective of this research was to show the diversity of Ivorian traditional dishes. The results showed that people from all ethnic groups consume traditional Ivorian compound foods. This diet oriented towards traditional dishes has also been found in studies conducted in Cameroon (Fotso et al., 1996). The results also showed the existence of several Ivorian traditional dishes produced by the indigenous populations on the national territory. These dishes composed of starchy main dishes and side sauces. The combination of a carbohydratebased dish and a vegetable or leafy vegetable-based sauce has social and economic, and nutritional origins (Gockowski et al., 2003). The basic dishes are made up of tubers and roots, namely yam, cassava, sweet potato, cocoyam or cereals such as rice, corn, millet, sorghum, fonio or plantain. The high consumption of these staple foods could be explained by their economic, nutritional importance, availability and accessibility. Since 1998, food production has increased considerably, with a balance sheet of more than 16 million tonnes in 2015 (Minader, 2016). Overall production of roots, tubers and plantains increased by $17.2 \%$ between 2000 and 2010 (6.67 to 7.82 million tonnes). For yam, production exceeded 5 million tonnes in 2005 coupled with a $30 \%$ drop in yield in 10 years due to the reduction in the fallow period (Minader, 2016). For plantain, production stagnated at around 1.5 million tonnes and average yields are between 3.7 and 4 tonnes / ha (Minader, 2016). It contributes significantly to the fight against food insecurity in sub-Saharan Africa where it is one of the main staple foods for more than one hundred million people (Frison and Sharrock, 1998; INIBAP, 2002). In Côte d'Ivoire, plantain has always been a very important traditional staple food for rural and urban populations (Soler and N'da, 1990). As for cassava, it is the second largest food crop in Côte d'Ivoire in terms of volume, with an estimated production of 5.09 million tonnes in 2015. After a drop in yields between 2008 and 2011 (7.7 tonnes/ha to 6.7 tonnes/ha), production improved from 2013 to 2015 with a yield increasing from 8.31 to 8.51 tons/ha (Minader, 2016). It is cultivated in almost all of Côte d'Ivoire (N'zué et al., 2004; Kouadio et al., 2010). Cassava is processed into placali (Koko et al., 2012), gari (James et al., 2013), attoukpou (Nevry et al., 2007) and especially attiéké (Assanvo et al., 2002; Tetchi et al., 2012; Krabi et al., 2015; Yao et al., 2015). To these basic dishes, sauces are added to modify their taste qualities and provide a valuable addition (proteins, minerals and vitamins). Moustier and David (2003) and Gbaguidi et al. (2007) have also shown that sauces accompany food consumption in Africa. Ivorian sauces are mainly composed of vegetables such as eggplant, peppers, leaves, onions, tomatoes, okra, seeds or legumes such as peanuts and pistachios accompanied by at least one 
source of protein such as fish, meat, game, poultry, molluscs, crustaceans, frogs or mushrooms and spices. The consumption of sauces can be explained by the availability and lower cost of the raw materials used in the preparation of sauces (Digbenou et al., 2003; Kwame and Andrew, 2005). In addition, in developing countries, leafy vegetables represent a low-cost food source of good nutritional quality (rich in minerals and vitamins) according to Tarwadi and Agte (2003). The composition of Ivorian traditional dishes is similar to that of African dishes. The latter are composed of tubers and roots, cereals, vegetables, fish, meat, oil, broth, potash, pepper and other spices (Avallone et al., 2007; Avallone et al. , 2008). The consumption of all Ivorian traditional dishes should be possible throughout the country, overcoming taboos, prejudices and certain customs. Thus, regular consumption of Ivorian traditional dishes would give new flavours, new tastes and would positively change consumers' eating habits. Concerning the protein contents, the conkondé with fresh okra sauce and cassava foutou with sran sauce contain low levels (10.44 and $10.94 \mathrm{~g} / 100 \mathrm{~g} \mathrm{DM}$ ). On the other hand, ripe plantain plus cassava foutou with eggplant sauce, white attiéké with light sauce, attiéké red palm oil with light sauce, cooked white rice with baouin sauce, yam foutou with namoukou sauce and plantain fufu with light sauce have normal protein contents ranging from 12.62 to $14.34 \mathrm{~g} /$ $100 \mathrm{~g} \mathrm{DM}$. These dishes with protein values between 12 and $15 \%$ comply with official recommendations indicating that the required protein level for a balanced meal is between 12 and $15 \%$ (CSS, 2009). These results are similar to those of Hecberg (1985) who showed that a reference dish would have a protein content of $15 \mathrm{~g} / 100 \mathrm{~g}$ DM. Ripe banana plus cassava foutou with tchêchra sauce, placali with seed sauce plus fresh okra, unripe banana plus cassava with biokosseu sauce and cassava with kpleba sauce have high contents (16.59 to $20.41 \mathrm{~g} / 100 \mathrm{~g} \mathrm{DM})$. These differences between the protein contents would be explained by the fact that the dishes are composed of different ingredients having different protein contents. In addition, the addition of different protein sources such as meat, fish or snails would partly explain these results. These results corroborate those of Azar et al., (1996). Indeed, in the evaluation of the nutritional composition of traditional rural dishes cooked in Iran, conducted by Azar et al., (1996), the dishes protein content of typically vegetable origin varied from 2.5 to $14.8 \mathrm{~g} / 100 \mathrm{~g}$ of dry matter, respectively for Kai-kadad and Eshkeneh-daneh. While meals made from both plant and animal foods had higher protein contents, up to $51.0 \mathrm{~g} / 100 \mathrm{DM}$ for
Bozghormed meals. All of the traditional Ivorian-type dishes evaluated had low lipid contents with values ranging from 4.43 to $29.78 \mathrm{~g} / 100 \mathrm{~g} \mathrm{DM}$ with the exception of plantain fufu with light sauce (PFF/LS) which had a normal amount of $31.10 \mathrm{~g} / 100 \mathrm{~g}$ DM. The lipid content of plantain fufu with light sauce would be due to the addition of red palm oil to the plantain fufu. Attiéké red palm oil with light sauce and white rice cooked with baouin sauce have lipid contents (28.06 and $29.78 \mathrm{~g} / 100 \mathrm{~g} \mathrm{DM}$ ) very close to the normal value (30$35 \%)$. Indeed, the recommended lipid content of a reference dish is between 30 and $35 \%$ (Ambroise, 2001). These results could be explained by the addition of red palm oil to the white attiéké and the use of palm seeds in the preparation of baouin sauce. The low lipid contents recorded would be the result of the low lipid poverty of the various ingredients used in the preparation of the dishes. Most of the traditional Ivorian-type had high total carbohydrate contents with values between 56.61 and $69.01 \mathrm{~g} / 100 \mathrm{~g}$ DM. Some dishes had normal amounts of total carbohydrates, between 50 and $55 \mathrm{~g} / 100 \mathrm{~g}$ DM as recommended by the CSS (2009) while the lowest values in total carbohydrates were between 45.65 and $48.91 \mathrm{~g} / 100 \mathrm{~g}$ DM. These comply with the EFSA (2010) standard, which recommends that carbohydrates provide between 45 and $60 \%$ of calorie intake. These total carbohydrate contents are due to the incorporation of tubers, roots or cereals that are naturally rich in carbohydrates. For example, cooked white rice contained $89.9 \mathrm{~g} / 100 \mathrm{~g}$ DM of total carbohydrates (Solomon, 1983). Green plantain pulp, potato pulp and corn husk contain between 70 and $80 \%$ starch, the main constituent of carbohydrates (Zhang et al., 2005). Dietary fiber is a non-digestible substance, the consumption of which has been associated with certain benefits, particularly on the cardiovascular and intestinal levels (Trumbo et al., 2002). They fight against certain types of cancer (Ponka et al., 2005). The fiber content of Ivorian dishes ranged from 2.1 to $6.76 \% \mathrm{DM}$. The low fiber content of Ivorian dishes is thought to be due to the low fiber content of the plants that make up these dishes. Moreover, all these dishes provided sufficient energy, between 373.33 and $516.78 \mathrm{Kcal} / 100 \mathrm{~g}$ of DM. These high calories are due to the protein, fat and carbohydrate content of the dishes. In fact, the literature indicates that starchy flours, being essentially made up of carbohydrates, are high-energy foods. These results are in agreement with those ( 473 to $598 \mathrm{Kcal} / 100 \mathrm{~g} \mathrm{DM}$ ) of Solomon (1983) in the study of cereal- and vegetablebased dishes. With regard to the mineral contents evaluated, all the dishes had low sodium, calcium and 
magnesium contents. Nevertheless, the majority of these dishes had a high iron content with values between 7.65 and $8.68 \mathrm{mg} / 100 \mathrm{~g}$ DM while some contained small amounts (5.63 and $6.01 \mathrm{mg} / 100 \mathrm{~g} \mathrm{DM})$. These low mineral contents are thought to be due to the diffusion loss of minerals in the cooking water. According to Slupski et al (2005), boiling reduces the mineral content of foods. However, a necessary amount remains in the

\section{CONCLUSION AND APPLICATION OF RESULTS}

There is a diversity of traditional dishes in Côte d'Ivoire. All traditional Ivorian dishes are rich in carbohydrates. Their protein contents are variable. Some have sufficient protein content and others have low levels. The majority of Ivorian dishes contain low levels of lipids. They provide the body with high energy. Their mineral

\section{REFERENCES}

AOAC, 1990. Official Methods of Analysis. 15 th (edn). Association of Official Analytical Chemists, Washington D.C, 1990.

AOAC, 1995. Official Methods of Analysis. Association of Agricultural Chemistry, Washington D.C 34 p.

Ambroise M., 2001. The"apports nutritionnels conseillés (ANC)" for the French population. Reproduction and Nutrition Development, EDP Sciences, 41(2):119-128.

Arimond M., Wiesmann D., Becquey E., Carriquiry A., Daniels M., Deitchler M., Fanou-Fogny N., Joseph M., Kennedy G., Martin-Prevel Y. and Torheim L. E., 2010. Simple food group diversity indicators predict micronutrient adequacy of women's diets in 5 diverse, resource-poor settings. Journal of Nutrition, 140: 2059S-69S.

Assanvo J. B., Agbo G. N., Behi Y. E. N., Coulin P. et Farah Z., 2002. La microflore du ferment du manioc pour la production de l'attiéké adioukrou de Dabou (Côte d'Ivoire); BIOTERRE, Revue Internationale des Sciences de la Vie et de la Terre, $\quad \mathrm{N}^{\circ}$ spécial, Acte du Colloque International, Centre Suisse, pp 286-299.

Atwater W. and Rosa E., 1899. A new respiratory calorimeter and the conservation of energy in human body. II-Physical Rev., 9: 214-251.

Avallone S., Brault S., Mouquet C. and Trèche S., 2007. Home- processing of the dishes constituting the main sources of micronutrients in the diet of preschool children in rural Burkina Faso. International Journal of Food Sciences and Nutrition, 58: 108-115. cooked food (Kawashima and Valente Soares, 2003). By associating milk or dairy products with the consumption of traditional Ivorian-type dishes, the calcium deficiency could be made up for. Consumption of foods of animal origin and legumes will alleviate anaemia problems. The regular consumption of fruits and vegetables would bring enough minerals including magnesium to the body.

composition is acceptable. Chemical characteristics show that regular consumption of traditional Ivorian dishes would provide carbohydrates, lipids, proteins and minerals for the proper functioning of the body of the consumer.

Avallone S., Tiemtore T. W. E., Mouquet-River C. and Trèche S., 2008. Nutritional value of six multiingredient sauces from Burkina Faso. Journal of Food Composition and Analysis, 21: 553-558.

Azar M. et Aminpour A., 1996. Composition et valeur nutritionnelle des mets traditionnels ruraux de l'Iran. Revue de santé de la Méditerranée orientale, 2(2): 261-267.

BIPEA, 1976. Bureau Interprofessionnel d'Etude Analytique. Recueil des Méthodes d'Analyses des Communautés Européennes. Greenville (France). $160 \mathrm{p}$.

CSS - Conseil supérieur de la Santé 2009. Recommandations nutritionnelles pour la Belgique. Révision 2009. Bruxelles: CSS; 2009. Avis $n^{\circ} 8309$.

Dally T., Méité A., Kouamé K. G., Bouafou K. G. M et Kati-Coulibali S., 2010. Efficacité nutritionnelle de trois mets ivoiriens: cabatoh à la sauce dah au nord; foutou igname à la sauce gouagouassou au centre; riz cuit à la sauce graine à l'ouest. Journal of Applied Biosciences, 33: 2084-2090.

Digbenou G., Addessi E., Galloway T. and Visalberghi E., 2003. Specific social influences on the acceptance of novel foods in 2-5 years old children. African food Journal and Nutrition, 45: 264-271.

EFSA-European Food Safety Authority, 2010. Scientific opinion on dietary reference values for carbohydrates and dietary fiber. EFSA Journal; 8(3):1462-1466. 
FAO, 1998. Techniques traditionnelles de traitement après récolte des principales denrées périssables tropicales. Rome, FAO \& PNUE.

Foote J., Murphy S., Wilkens L., Basiotis P. and Carlson A., 2004. Dietary variety increases the probability of nutrient adequacy among adults. Journal of Nutrition, 134: 1779-1785.

Fotso M., Mbome L. L. et Trèche S., 1996. Amélioration de la qualité nutritionnelle des foutous et bouillies à base de maïs, manioc et d'igname par la supplémentation avec du soja. Cahiers agriculture ORSTOM fonds documentaire 41(559): 369-370.

Frison E. A. et Sharrock S., 1998. Les productions bananières: un enjeu économique majeur pour la sécurité alimentaire. Symposium International, Douala, Cameroun, 10-14 November 1988. INIBAP, Montpellier, France.

Gbaguidi A., Digbenou G. and Koffi H., 2007. Nutrition and food consumption in children under five years. Journal of Health, 13: 84-98.

Gockowski J., Mbazo'o G., Mbah T, and Moulende F., 2003. African traditional leafy vegetables and the urban and peri-urbain poor. Food Policy, 28: 221-235.

Hecberg S., Duplin H., Papaz L. et Galan P., 1985. Santé publique et nutrition, $51 \mathrm{p}$.

INIBAP: International Network for the Improvement of Banana and Plantain, 2002. Networking banana and plantain. INIBAP Annual Report 2001. Montpellier, France: INIBAP.

James B., Okechukwu R., Abass A., Fannah S., MaziyaDixon B., Sanni L., Osei-Sarfoh A., Fomba S. et Lukombo S. 2013. Production du Gari à Partir de Manioc: Guide Illustré à l'Intention des Transformateurs de Manioc à Petite Echelle. Institut International d'Agriculture Tropicale (IITA): Ibadan, Nigeria; $32 \mathrm{p}$.

Kawashima L. M. and Valente-Soares L. M., 2003. Mineral profile of raw and cooked leafy vegetables consumed in Southern Brazil. Journal of Food Composition and Analysis, 16: 605-611.

Kennedy G., Pedro M. R., Seghieri C., Nantel G. and Brouwer I., 2007. Dietary diversity score is a useful indicator of micronutrient intake in nonbreast-feeding Filipino children. Journal of Nutrition, 137: 1-6

Koko A. C., Konan A., Tetchi F., Assidjo E. and Amani G., 2012. Quality of fermented cassava flour processed into plakali. International Journal of
Biology and Chemistry Sciences, 6(1): 415420.

Kouadio K. K. H., Dao D., Tschannen A. et Girardin O., 2010. Rentabilité comparative des granulés de manioc natifs. International Journal of Biology and Chemistry Science, 9(3): 1341-1353.

Krabi E. R., Assamoi A. A., Ehon A. F., Bréhima D., Niamké L. S. et Thonart P., 2015. Production d'attiéké (couscous à base de manioc fermenté) dans la ville d'Abidjan. European Scientific Journal, 11(15): 277-292.

Kwame K. and Andrew M., 2005. Prevalence of picky eaters among infants and toddlers and their caregivers decisions about offering a new food. Journal of American Dietetics Association, 4: 57-64.

Minader, 2016. Ministère de l'agriculture et du développement rural de Côte d'Ivoire.

Mirmiran P., Azadbakht L., Esmaillzadeh A. and Azizi F., 2004. Dietary diversity score in adolescents- a good indicator of the nutritional adequacy of diets: Tehran lipid and glucose study. Asia Pacific Journal of Clinical Nutrition, 13(1): 5660.

Moustier D. and David A., 2003. Effects of peer Models Food Choices and Eating Behaviors on Preschoolers Food Preferences, Child Development 51: 489-496.

N'zué B., Zohouri P. G. et Sangare A., 2004. Performance agronomique de quelques variétés de manioc de trois zones agroclimatiques de la Côte d'Ivoire. Agronomie Africaine, 16(2): 1-7.

Nevry K. R., Koussemon M. and Aboua F., 2007. Chemical and organoleptic properties of attoukpou made from two cassava (Manihot esculenta Crantz) varieties, Bonoua and IAC. Journal of Food Technology, 5(4): 300-304.

Pauwels J. N., VAN Ranst E., Verloo M. et Mvondo Z. E., 1992. Manuel de laboratoire et pédologie: Méthode d'analyse de sol et de plantes, équipement, gestion de stocks de verrerie et de produits chimiques. Publications agricoles 28 , Belgique, $256 \mathrm{p}$.

Ponka R., Fokou E., Leke R., Fotso M., Souopgui J., Achu B. M. and Miapo Tchouanguep P. F., 2005. Methods of preparation and nutritional evaluation of dishes consumed in malaria endemic zone in Cameroon (Ngali II). Department of biochemistry faculty of science, Faculty of medecine and biomedical Sciences, 
University of Yaoundé I, Cameroon ; center for reseach in food and nutrition IMPM Youndé Cameroon ; African Journal of Biotechnology, 4(3): 273-278.

Slupski J., Lisiewska Z. and Kmiecik W., 2005. Contents of macro and microelements in fresh and frozen dill (Anethum graveolens L.). Food Chemistry, 91: 737-743.

Soler A. et N'Da Adopo A., 1990. Amélioration des systèmes post-récoltes. Séminaire du Programme Pluridisciplinaire du 29-01 au 0102-1990, (Abidjan, Côte d'Ivoire). CIRAD-IRFA, $9 \mathrm{p.}$

Solomon D., 1983. In l'alimentation risque majeur, écologie systémique: Negre Robert. Edition Marketing (Paris) 19: 311-318.

Steyn N. P., Nel J. H., Nantel G., Kennedy G. and Labadarios D., 2006. Food variety and dietary diversity scores in children: are they good indicators of dietary adequacy? Public Health Nutrition, 9(5): 644-650.

Tarwadi K. and Agte V., 2003. Potential of commonly consumed green leafy vegetables for their antioxidant capacity and its linkage with the micronutrient profile. International Journal of Food Sciences and Nutrition, 54: 417-425.

Tetchi F. A., Solomen O. W., Celah K. A. and Georges A. N., 2012. Effect of cassava variety and time on biochemical and microbiological characteristics of raw artisanal starter for attiéké production. Innovative Romanian Food Biotechnology, 10: 40-47.

Trumbo P., Schlider S. A., Yates A. and Poos M., 2002. Dietary Reference Intakes for Energy, Carbohydrate, Fiber, Fat, Fatty Acids, Cholesterol, Protein, and Amino Acids, Journal of the American Dietetic Association, 102 (11): 1621-1630.

Yao K. A, Koffi D. M., Blei S. H., Irié Bi Z. et Niamké L. S., 2015. Propriétés biochimiques et organoleptiques de trois mets traditionnels ivoiriens (attiéké, placali, attoukpou) à base de granulés de manioc natifs. International Journal of Biology and Chemistry Sciences, 9(3): 13411353.

Zhang P., Whistler R. L., Be Miller J. N. and Hamaker B. R., 2005. Banana starch: Production, Physicochemical properties and digestibility, a review. Carbohydrate Polymers, 59(4): 443458. 